\title{
Ethical, Business, and Management Views of China's Next Generation: A Quantitative Study of Chinese Undergraduate Students for Improved Pedagogy and More Effective East-West Business Interaction
}

\author{
William E. Allen \\ Correspondence: William E. Allen, Ph.D., Fort Hays State University, RCOBE College of Business and Entrepreneurship, \\ 600 Park Street, Hays, KS 67601, USA.
}

Received: February 18, 2019

doi:10.11114/bms.v5i1.4131
Accepted: March 4, $2019 \quad$ Online Published: March 10, 2019

URL: https://doi.org/10.11114/bms.v5i1.4131

\begin{abstract}
The purpose of this quantitative research is to explore Chinese undergraduate student worldviews and the foundation upon which those views are constructed. This study sheds light on neglected aspects of the changing global economy in its demand for consistent global ethics and a blending of Eastern and Western approaches to business and management that meet the needs of all stakeholders. The results of this study may lead to a better understanding for Western educators and business practitioners when dealing with Chinese students or clients in a cross-cultural environment.
\end{abstract}

Keywords: cross-cultural, China, ethics, business, management, Western, worldview, pedagogy

\section{Introduction}

Contemporary management theory derives primarily from Western theory and research (Chemers, 1995; Komives, Lucas, \& McMahon, 2007; Perkins, 2009) though tremendous efforts have been made to dissect the differences among cultures for cross-cultural adaptation (Giddens, 2003; Hofstede \& Hofstede, 2005; House, Hanges, Javidan, Dorfman, \& Gupta, 2004; Zimmerman, 2015). The necessary skill of cross-cultural competency in a global environment equips leaders to interact with all stakeholders in a multi-culturally appropriate manner (Beechler \& Javidan, 2007; Bird, Medenhall, Oddou, \& Stevens, 2010; Goldsmith, 2000; House et al., 2004; Mendenhall, Osland, Bird, Oddou, \& Maznevski, 2008). Lists of important attributes for global leaders continue to emerge with the understanding that cross-cultural competency ranks among the most important leadership attributes ((Beechler \& Javidan, 2007; Goldsmith et al., 2000; Goryunova \& Jenkins, 2017; Mendenhall et al., 2008; Moro \& Tubbs, 2004).

Culture indicates a shared system of beliefs, values, behaviors, and assumptions in a group of people (Cheng, 2005; Pettigrew, 1979; Schein, 1992; Schwartz \& Davis, 1981). The increase of globalization demands cross-cultural adaptations in all areas of commerce including education (McInerney \& Liem, 2008). Global interconnectedness requires cross-cultural understanding and comprehensive skills for effective communication and awareness in education (Durant \& Shepherd, 2009; Ozturgut, 2007). Educators must remember their own assumptions, beliefs, values, behaviors, and expectations all originate from their own culture and in a new culture these standards no longer apply (Zimmerman, 2015).

The affirmation that cross-cultural education directly relates to the effect of globalization (Bennett \& Salonen, 2007) also requires a broader and deeper appreciation of cultural differences (White, 2008). Western educators teaching in Eastern settings and those in a domestic classroom with a multicultural students must develop understanding and adapt their pedagogy (Fall, Kelly, MacDonald, Primm, \& Holmes, 2013). Thus, educators must make efforts to adapt and build pedagogical bridges in the interest of meeting the needs of multicultural students (Lee \& Rice, 2007; Shek \& Lin, 2016).

There is a need to understand and even articulate the cultural value foundations upon which cultural rules have been constructed (Perkins, 2009). Eastern values emphasize collectivism, harmony, pragmatism, and the long-term view of relational interaction often clashes with Western emphasis on integrity, individualism and short-term efficacy (Hofstede et al., 2005). Authoritarian leadership often witnessed in Eastern cultures is considered outdated and unsophisticated by Western observers; however, the rigid leadership roles accepted in Eastern cultures provide certainty and security in a model built upon thousands of years of implementation (Hofstede et al., 2005). An individual's culture represents the window that the rest of the world must pass through for the individual to understand their surroundings (Hofstede et al., 
2005; Habermas \& Bluck, 2000; Quinn, 2003). Cross-cultural interactions change individuals' frames of reference and understandings of reality (Bennett, 2004). This study seeks to increase that understanding for Western educators and Western business people in China.

Genuine cross-cultural competency starts in the classroom where Western educators dispense Western management theory to students of Eastern or other cultural heritage. Efforts to engage students and to blend Eastern and Western approaches to management help to bridge the gap however that only addresses superficial and initial needs. Freedom for students to assimilate Western theory, to experience the unsettling of their worldview, and to adjust with an accommodation of new ideas into their own perspective enables future Eastern leaders to truly appreciate and make use of Western contributions. Improved insight into Chinese student perspectives can guide Western pedagogical adaptations for a better teaching and learning experience and for better applications in the global marketplace.

This research builds on prior efforts to blend cultural approaches to management and to equip Western management educators and business practitioners with the needed understanding for improved outcomes in cross-cultural management. It addresses a felt need to understand Chinese thinking about business ethics and management. The study is based on ten years of teaching experience in cross-cultural higher education, most recently in China in a business management program. Better understanding of Chinese undergraduate student worldviews may benefit pedagogy, research, and practice among people of Western and Eastern cultures for more efficacious cross-cultural interaction. This quantitative research study is the first step in a multiphase research project to determine the underlying motivations, thinking, and worldview of Chinese undergraduate students as well as managers in the Chinese marketplace. One broader goal of this study is to discern the most effective methods, techniques and approaches in the working out of an East meets West business or academic environment where the best of both cultures is combined.

\section{Literature Review}

The rapid changes in commerce and technology occurring in the world today stem from globalization and the need for understanding and adapting to political, economic, and social changes (Perkins, 2009). Nevertheless, cultural worldviews and societal values continue to be the primary foundation for people as they work at cross-cultural engagement (Dorfman, Hanges, \& Brodbeck, 2004; Giddens, 2003). The values, beliefs, and ideas of a culture that derive from its history impact the cultural view of management and the methods by which leaders emerge (Perkins, 2009). The GLOBE Study of 62 Societies by House provides the basis for developing and understanding 9 cultural dimensions (power distance, uncertainty avoidance, humane orientation, institutional and group collectivism, assertiveness, gender egalitarianism, future orientation and performance orientation) across the world and the related impact on manager effectiveness (House, et al., 2004). The Study also identified the need to understand and address cultural influences and nuances in adapting management to practical societal and global requirements (Dorfman et al., 2004).

With internationalization increasingly becoming the norm for universities around the world (Jones \& Killick, 2013), studies have largely focused on international students at Western universities (Spencer-Oatey, Dauber, Jing, \& Lifei, 2017; Yuan, Li \& Yu, 2018). Data on students at non-western campuses enrolled in Western programs is lacking. This study addresses the gap regarding Chinese students' perceptions and experiences at international universities based on the perceived need and current Chinese efforts to attract international professors for Chinese universities (Huang, 2015; Ryan, 2011; Yuan, et al., 2018).

Studies considering demographic (socio-economic background, parental level of education, etc.) or contextual (school environment) impact on student academic achievement are lacking with the gap widening considerably regarding Chinese students (Crede, Wirthwein, McElvaney, \& Steinmayr, 2015). Chinese educational resources and research are heavily focused on big cities (Xue \& Xue, 2002) resulting in a gap related to research on student background, household income, lifestyle and attitudes at more rural schools therein justifying inquiry (Balsas, 2003). Cultural differences in many areas of cognition shape an understanding of reality and occupational and educational planning for the future (Henrich, Neine, \& Norenzayan, 2010) and enable individuals to determine what is normal and desirable on issues of ethics, management, and the level of importance placed on traditional culture (Bonn \& Lian, 2016).

Chinese reliance on the Chinese Communist Party (CCP) for a coherent system of meaning has been replaced in the hearts of many Chinese with a search for a faith belief system (Yang, 2015). Studies examining the relationship between CCP membership and science education have been performed (Li, LU, \& Yang, 2018), as have studies related to Chinese faith beliefs and life satisfaction noting positive correlations (Bonn \& Lian, 2016). However, research into relationships between $\mathrm{CCP}$ membership and ethics, approaches to management, and opinions on traditional Chinese culture is lacking.

Issues related to academic honesty among Chinese students have been well researched (La Roche 2011; Rawwas, Al-Khatib, \& Vitell 2004; Li, 2007; Mu \& Xu, 2009; Qin, 2013; Zhang, 2012). More recent research indicates the perceived willingness of Chinese students to commit academic honesty is better understood as part of an enculturation 
process where an educative rather than a punitive approach is recommended (Hu \& Lei, 2014). However, none of these researchers attempt to tie this cultural difference to the broader variables of ethics and management as is the focus of this study.

Chinese student demographics such as business major or traditional inclinations have been studied in relation to student identity in international programs finding that parental influence heavily influences the choice of a major (Yuan et al., 2018). Chinese traditional cultural impact on classroom behavior has also been examined noting Chinese student reluctance to ask or answer questions (Li \& Wegerif, 2014). However, there is a gap as to whether these variables are predictive of ethics or management views.

Chinese students face a difficult challenge transitioning from the university to a career because of the record number of university graduates competing for jobs in China (Guan, Capezio, Restubog, Read, Lajom, \& Li, 2016; Tian \& Fan, 2013). The family impact on career choice (Garcia, Restubog, Toledano, Tolentino, \& Rafferty, 2011), the need for parental physical and emotional support during life transitions (Turner, Alliman-Brissett, Lapan, Udipi, \& Ergun, 2003), and the related confidence and motivation to embrace challenges as a result of this support (Garcia et al., 2011; Ginevra, Nota, \& Ferrari, 2015; Guan et al., 2015) is well documented. Familial impact on career choices have been studied (Savickas, 2013). These effects are heightened in Chinese society where a commitment to traditional values is directly associated with student career choices in line with parental wishes (Leung, Hou, Gati, \& Li, 2011; Yang, 2003). However, research is lacking to determine whether any relationship exists among these variables and their predictive value on matters of ethics, management views, or attitudes regarding traditional Chinese culture.

University campuses have been found to be less open to religious ideals than in the past (Caplovitz, 1977; Hunter, 1983). On Chinese campuses, in particular, state atheism actively minimizes the presence and impact of religious thought among the student body and, the effect is even greater where political instruction on atheism and nationalism is part of the curriculum ( $\mathrm{Li}$ et al., 2018). Nevertheless, students in these environments may still understand their daily life through religious tenets (Lehman \& Shriver, 1968; O'Brien \& Noy, 2015). This study presses further with a look at whether these variables among Chinese students have any relationship to ethical attitudes, management principles and/or attitudes regarding traditional Chinese culture.

Positive relationships between educational achievement and job opportunity have been established (Kadison \& DiGeronimo, 2004; Rana \& Mahmood, 2010) and socio-economic variables such as parental education, income and occupation are common contextual variables used in education research (Hauser, 1994; Sirin, 2005). These variables can positively influence student academic success (Crede et al., 2015; Kim \& Sherradin, 2011; Steinmayr, Meisner, Weidinger, \& Wirthwein, 2014). This study, in the Chinese setting, examines these variables to ascertain whether any predictive relationship exists regarding student attitudes on ethics, management principles and/or a predisposition to traditional Chinese cultural mores.

Western cross-cultural teachers in Asia who work to create a learning environment utilizing both Western and Eastern pedagogy excel in the classroom (Tang, 2009). A sense of urgency in developing effective pedagogy should exist because culture impacts how students and teachers learn, comprehend, and perceive the world (Crotty, 1998; Diaz-Rico \& Weed, 2010; Friend, Most, \& McCrary, 2009). Educators have a responsibility to guide students through the process of discovering their own cultural bias (Posner, 2009). This study is the initial effort to discover the foundation underlying Chinese undergraduate student worldviews for the purpose of adapting Western-based management course instruction. Cross-cultural teachers need to embrace both a global vision and a local awareness to help students in an international program confront their identity paradoxes and fully engage in academic learning (Yuan et al., 2018).

This study seeks to address these gaps by answering the following research questions about Chinese undergraduate student attitudes on ethics, management, and traditional Chinese culture:

1. To what degree do political party membership, gender, academic major, belief system, parental occupation and parental education level predict ethical attitudes of Chinese undergraduate students?

2. To what degree do political party membership, gender, academic major, belief system, parental occupation and parental education level predict management principle attitudes of Chinese undergraduate students?

3. To what degree do political party membership, gender, academic major, belief system, parental occupation and parental education level predict attitudes about traditional Chinese culture of Chinese undergraduate students?

\section{Methods}

\subsection{Participants}

Survey data was gathered at an undergraduate university in rural Central China. The sample size was 405 out of a student population of approximately 22,000. An additional 4,500 students involved with a dual degree program from the 
partner American university were excluded from the study to eliminate bias from any name recognition of the surveyor. A post-hoc power analysis in $G^{*}$ Power (Erdfelder, Faul, Lang, \& Buchner, 2007) for a logistic regression based on the sample size and assuming a medium-sized effect (odds ratio of 1.3) showed the statistical power for this study was 0.74 ; or a $74 \%$ chance of finding significant results for the regression analyses with the sample size. Institutional Review Board (IRB) approval was obtained from the researcher's American university with authorization received as well from the Chinese partner university.

\subsection{Data Collection}

This study used the snowball method of respondent recruitment (Baltar \& Brunet, 2012; Nietzen \& Mathijssen, 2014) during the spring semester of 2018. The survey was administered electronically through popular Chinese social media platforms, which included Weibo, QQ.com, and WeChat. Participation of survey respondents was strictly voluntary and though demographic information such as gender, major, and class year was collected, individual respondents were not identifiable. Informed consent was collected electronically before students had access to the survey instrument. If the student denied consent, access to the survey was terminated.

\subsection{Instrument}

The survey instrument used in this study was an amalgamation and an adaptation of several instruments used by Pew Research, Gallup Poll, Barna Research Group, The GLOBE Project, the Chinese State Administration for Religious Affairs, and the American National Election Studies Time Series Study. A series of mock survey administrations were conducted with four different translators in order to translate the questions from English to Chinese. Back-translation was undertaken however test-retest procedures were not (Erdvik, Overby, \& Haugen, 2015). The survey instrument included 28 questions of which the first 26 were demographic/factual in nature as independent variables and were designed to yield a descriptive understanding of the survey sample. Questions 27 and 28 asked for an "agree/disagree" response on a variety of statements relating to ethics, management principles, and traditional Chinese culture as the dependent variables.

\section{Results}

Descriptive statistics and cross tabulations were conducted to characterize the sample. Binary logistic regressions were conducted to address the research questions. Intellectus Statistics software was used for all data analyses. It is acknowledged that the data captured only a fleeting moment in time much the same as a camera taking a single photograph of an ongoing activity (Leedy \& Ormrod, 2010).

\subsection{Sample Characteristics}

A total of 405 students completed the survey. Table 1 displays descriptive statistics for the students' basic demographic information. Most of the students were women $(n=260,64 \%)$ and the largest proportion of students were in their third year $(n=130,32 \%)$. The most common major was business $(n=171,42 \%)$ and the majority of students indicated their main source of financial support was from their parents $(n=340,84 \%)$. Note: for all tables that follow, due to rounding errors, percentages may not equal $100 \%$. 
Table 1. Frequency Table for Basic Demographic Characteristics

\begin{tabular}{|c|c|c|}
\hline Variable & $n$ & $\%$ \\
\hline \multicolumn{3}{|l|}{ Gender } \\
\hline Female & 260 & 64.20 \\
\hline Male & 145 & 35.80 \\
\hline \multicolumn{3}{|l|}{ Year at University } \\
\hline 1 & 125 & 30.86 \\
\hline 2 & 124 & 30.62 \\
\hline 3 & 130 & 32.10 \\
\hline 4 & 26 & 6.42 \\
\hline \multicolumn{3}{|l|}{ Major } \\
\hline Business & 171 & 42.22 \\
\hline Foreign Language & 32 & 7.90 \\
\hline Law & 19 & 4.69 \\
\hline Electronics & 55 & 13.58 \\
\hline Art and Design & 18 & 4.44 \\
\hline Physical Education & 14 & 3.46 \\
\hline Music & 4 & 0.99 \\
\hline Other & 88 & 21.73 \\
\hline Architecture & 4 & 0.99 \\
\hline \multicolumn{3}{|l|}{ Financial Support } \\
\hline Parents & 340 & 83.95 \\
\hline SIAS Scholarship & 8 & 1.98 \\
\hline Self & 12 & 2.96 \\
\hline Chinese Government Scholarship & 9 & 2.22 \\
\hline Relatives & 4 & 0.99 \\
\hline Loan & 23 & 5.68 \\
\hline Family Friend & 1 & 0.25 \\
\hline Other & 8 & 1.98 \\
\hline \multicolumn{3}{|l|}{ Campus Organization Involvement } \\
\hline None & 86 & 21.23 \\
\hline 1 & 161 & 39.75 \\
\hline 2 & 108 & 26.67 \\
\hline 3 & 44 & 10.86 \\
\hline 4 & 2 & 0.49 \\
\hline More than 4 organizations & 4 & 0.99 \\
\hline
\end{tabular}

Table 2 displays descriptive statistics for the students' family characteristics. The largest proportion of students indicated their fathers were employed as small business owners $(n=101,25 \%)$ and that their mothers worked occasionally or from home $(n=108,27 \%)$. Most participants had one sibling $(n=206,51 \%)$. The majority of students indicated that their parents and grandparents had no belief system. Most participants did not have a college-educated parent $(n=289,71 \%)$. 
Table 2. Frequency Table for Family Characteristics

\begin{tabular}{|c|c|c|}
\hline Variable & $n$ & $\%$ \\
\hline \multicolumn{3}{|l|}{ Father Employment } \\
\hline Occasional or Home & 58 & 14.32 \\
\hline Farmer & 85 & 20.99 \\
\hline Laborer & 55 & 13.58 \\
\hline Skilled Worker & 25 & 6.17 \\
\hline Small Business Owner & 101 & 24.94 \\
\hline White Collar Job & 12 & 2.96 \\
\hline Managerial Job & 49 & 12.10 \\
\hline Unemployed & 20 & 4.94 \\
\hline \multicolumn{3}{|l|}{ Mother Employment } \\
\hline Occasional or Home & 108 & 26.67 \\
\hline Farmer & 91 & 22.47 \\
\hline Laborer & 32 & 7.90 \\
\hline Skilled Worker & 14 & 3.46 \\
\hline Small Business Owner & 80 & 19.75 \\
\hline White Collar Job & 17 & 4.20 \\
\hline Managerial Job & 36 & 8.89 \\
\hline Unemployed & 27 & 6.67 \\
\hline \multicolumn{3}{|l|}{ Number of Siblings } \\
\hline None & 92 & 22.72 \\
\hline 1 & 206 & 50.86 \\
\hline 2 & 83 & 20.49 \\
\hline 3 & 20 & 4.94 \\
\hline \multicolumn{3}{|l|}{ Mother's Belief System } \\
\hline None & 312 & 77.04 \\
\hline Buddhism & 46 & 11.36 \\
\hline Islam & 2 & 0.49 \\
\hline Daoism & 1 & 0.25 \\
\hline Chinese Folk Beliefs & 11 & 2.72 \\
\hline Christian & 24 & 5.93 \\
\hline \multicolumn{3}{|l|}{ Father's Belief System } \\
\hline None & 347 & 85.68 \\
\hline Buddhism & 31 & 7.65 \\
\hline Islam & 1 & 0.25 \\
\hline Daoism & 2 & 0.49 \\
\hline Chinese Folk Beliefs & 9 & 2.22 \\
\hline Christian & 8 & 1.98 \\
\hline $\begin{array}{l}\text { Other } \\
\text { Father's Parent's Belief System }\end{array}$ & 7 & 1.73 \\
\hline None & 269 & 66.42 \\
\hline Buddhism & 55 & 13.58 \\
\hline
\end{tabular}


Table 2. Continued

\begin{tabular}{lll}
\hline Islam & 3 & 0.74 \\
Daoism & 6 & 1.48 \\
Chinese Folk Beliefs & 23 & 5.68 \\
Christian & 36 & 8.89 \\
Others & 13 & 3.21 \\
Mother's Parent's Belief System & & 69.88 \\
None & 283 & 12.59 \\
Buddhism & 51 & 0.49 \\
Islam & 2 & 0.99 \\
Daoism & 4 & 4.69 \\
Chinese Folk Beliefs & 19 & 8.64 \\
Christian & 35 & 2.72 \\
Other & 11 & \\
Parent's Education & & 71.36 \\
Neither College Educated & 289 & 13.09 \\
One College Educated & 53 & 15.56 \\
Both College Educated & 63 & \\
Parent Contact & & 11.36 \\
Less Than Monthly & 46 & 11.36 \\
Every Month & 46 & 60.49 \\
Every Week & 245 & 16.79 \\
Everyday & 68 & \\
\hline
\end{tabular}

Table 3 displays a summary of students' political party affiliation and whether they use a Virtual Private Network (VPN) to visit Chinese government censored websites. A large majority of students indicated that they were members of the Chinese Communist Youth League $(n=352,87 \%)$. Approximately one quarter of students admitted to using a VPN $(n=$ $101,25 \%)$.

Table 3. Frequency Table for Political Party Affiliation and Use of Virtual Private Network

\begin{tabular}{lll}
\hline Variable & $n$ & $\%$ \\
\hline Party Membership & & \\
Chinese Communist Party & 37 & 9.14 \\
Chinese Communist Youth League & 352 & 86.91 \\
Neither & 16 & 3.95 \\
Use a Virtual Private Network (VPN) for internet access & 101 & 24.93 \\
\hline
\end{tabular}

Table 4 shows descriptive statistics pertaining to student's beliefs. Most students had no belief system $(n=338,83 \%)$ and did not believe in God $(n=331,82 \%)$. Likewise, most students did not believe in life after death $(n=273,67 \%)$ or judgment after death $(n=352,87 \%)$. 
Table 4. Frequency Table for Student Beliefs

\begin{tabular}{lll}
\hline Variable & $n$ & $\%$ \\
\hline Belief System & 338 & 83.46 \\
None & 23 & 5.68 \\
Buddhism & 3 & 0.74 \\
Islam & 2 & 0.49 \\
Daoism & 22 & 5.43 \\
Chinese Folk Beliefs & 8 & 1.98 \\
Christian & 9 & 2.22 \\
Other & & 18.27 \\
Believe in God & 74 & 81.73 \\
Yes & 331 & 32.59 \\
No & & 67.41 \\
Believe in Life After Death & 132 \\
Yes & 273 \\
No & & 13.09 \\
Believe in Judgment After Death & 53 \\
Yes & 352 & 86.91 \\
No & & \\
\hline
\end{tabular}

Table 5 summarizes students' responses to the items pertaining to ethical beliefs, business-related beliefs, and traditional Chinese values. Only $17 \%$ of respondents agreed that maintaining relationships is more important than honesty, and $48 \%$ of students agreed that they trust most people around them. In response to whether Chinese business leaders must be controlling, 40\% agreed and only 12\% agreed that Chinese workers are trustworthy. Regarding gender equality, $72 \%$ agreed that men and women should be equal for job opportunities however only $52 \%$ agreed that men and women should be equal for employment pay. Approximately 39\% of students agreed that most students copy at least some assignments, and $24 \%$ agreed that most students cheat on at least some exams. About $19 \%$ of students agreed that it is ok to temporarily break rules to achieve a goal and $62 \%$ agreed that they would do anything to avoid shaming their family. Regarding whether traditional Chinese values are important to keep, 55\% agreed, in addition, $46 \%$ agreed that their greatest responsibility in life is making sure they can take care of their parents, and $41 \%$ agreed that harmony is more important than resolving conflict. 
Table 5. Frequency Table for Ethical Beliefs, Business-Related Beliefs, and Traditional Chinese Values

\begin{tabular}{|c|c|c|}
\hline Variable & $\begin{array}{l}\text { Number of Students } \\
\text { Agreed }\end{array}$ & $\%$ of Students Agreed \\
\hline There is no absolute truth. & 268 & 66.17 \\
\hline Truth depends on the situation. & 172 & 42.47 \\
\hline I trust most people around me. & 196 & 48.40 \\
\hline Maintaining relationships is more important than honesty. & 67 & 16.54 \\
\hline Employment relationships are more important than job competency. & 27 & 6.67 \\
\hline Men and women should be equal for job opportunities. & 293 & 72.35 \\
\hline Men and women should be equal for employment pay. & 209 & 51.60 \\
\hline Men are better leaders than women. & 35 & 8.64 \\
\hline In business, sharing power with subordinates brings better results. & 142 & 35.06 \\
\hline Copying on assignments is ok. & 13 & 3.21 \\
\hline Most students copy at least some assignments. & 157 & 38.77 \\
\hline Cheating on exams is ok. & 9 & 2.22 \\
\hline Most students cheat on at least some exams. & 97 & 23.95 \\
\hline Leaders in Chinese business must be controlling. & 164 & 40.49 \\
\hline Chinese workers are trustworthy & 48 & 11.85 \\
\hline $\begin{array}{l}\text { Chinese business culture requires a man to be able to drink large amounts of } \\
\text { alcohol. }\end{array}$ & 84 & 20.74 \\
\hline If a shopkeeper gives too much change, it is ok to keep the extra money. & 21 & 5.19 \\
\hline It is ok to break traffic rules if there are no street cameras. & 16 & 3.95 \\
\hline I would do anything to avoid shaming my family. & 252 & 62.22 \\
\hline Traditional Chinese values are important to keep. & 223 & 55.06 \\
\hline Harmony is more important than resolving conflict. & 165 & 40.74 \\
\hline Managers and workers cannot be social friends. & 14 & 3.46 \\
\hline Ethics can be postponed to gain wealth. & 7 & 1.73 \\
\hline My personal morals and beliefs are influenced mostly by the government. & 27 & 6.67 \\
\hline My greatest responsibility in life is making sure I can take care of my parents. & 188 & 46.42 \\
\hline It is ok to temporarily break rules to achieve a goal. & 75 & 18.52 \\
\hline
\end{tabular}

\subsection{Crosstab Analysis}

Limited crosstab analysis was conducted to compare subsets of the sample with the overall sample characteristics. Tables $6,7,8$, and 9 compare business students, those whose fathers are small business owners, CCP members, and parental level of education with the sample population. Business students scored low for agreeing that relationships are more important than honesty, and that men are better leaders than women. Students whose fathers are small business owners were comparatively low in agreeing males and females should receive equal pay. Student members of the CCP were higher in the use of a Virtual Private Network (VPN), lower in agreeing in gender equality and higher in the area of spiritual beliefs. Higher levels of parental education was negatively correlated with compliance with government VPN restrictions, agreement on gender equality, and a feeling of responsibility for taking care of one's parents.

Table 6. Crosstab Analysis for Business Majors

\begin{tabular}{lll}
\hline Variable & \% of BM & Sample \% \\
\hline Alcohol use & 44 & 42 \\
Maintaining relationships is more important than honesty - agree & 12 & 17 \\
Male/female equal pay - agree & 50 & 72 \\
Men are better leaders than women - agree & 8 & 9 \\
Chinese culture requires a man to drink large amounts of alcohol - agree & 20 & 21 \\
Would do anything to avoid shaming family - agree & 65 & 62 \\
Power sharing with subordinates brings better results - agree & 35 & 35 \\
Chinese workers are trustworthy - agree & 12 & 12 \\
Ok to break traffic rules if no cameras - agree & 2 & 4 \\
Traditional Chinese values are important to keep - agree & 56 & 55 \\
Harmony more important than resolving conflict - agree & 40 & 41 \\
Managers and workers cannot be social friends - agree & 2 & 3 \\
\hline
\end{tabular}


Table 7. Crosstab Analysis for Students Whose Fathers are Small Business Owners

\begin{tabular}{lll}
\hline Variable & \% of SB & Sample \% \\
\hline Truth depends on the situation - agree & 51 & 43 \\
I trust most people around me - agree & 54 & 49 \\
Maintaining relationships is more important than honesty - agree & 10 & 17 \\
Employment relationships more important than job competency - agree & 10 & 7 \\
Men and women should be equal for job opportunities - agree & 73 & 72 \\
Male/female equal pay - agree & 56 & 72 \\
Men are better leaders than women - agree & 5 & 9 \\
Chinese workers are trustworthy - agree & 17 & 12 \\
Would do anything to avoid shaming my family - agree & 65 & 62 \\
Chinese values are important to keep - agree & 50 & 55 \\
Greatest responsibility in life is taking care of parents - agree & 41 & 46 \\
Ethics can be postponed to gain wealth - agree & 0 & 2 \\
Ok to temporarily break rules to achieve a goal - agree & 19 & 19
\end{tabular}

Table 8. Crosstab Analysis for CCP Members

\begin{tabular}{llll}
\hline Variable & $\begin{array}{l}\text { \% of } \\
\text { CCP }\end{array}$ & $\begin{array}{l}\text { \% of } \\
\text { CCYL }\end{array}$ & Sample\% \\
\hline Member - yes & 9 & 87 & same \\
Use a VPN - yes & 43 & 22 & 25 \\
Believe in God or some type of Supreme Being - yes & 24 & 18 & 18 \\
Believe in some type of spiritual life after death - yes & 38 & 31 & 33 \\
Men and women equal for job opportunities - agree & 49 & 75 & 72 \\
Would do anything to avoid shaming my family - agree & 35 & 66 & 62 \\
Chinese values are important to keep - agree & 62 & 55 & 55 \\
Greatest responsibility in life is taking care of parents - agree & 35 & 49 & 46
\end{tabular}

Table 9. Crosstab Analysis for Parental Level of Education

\begin{tabular}{llll}
\hline Variable & $\%$ of B & \% of N & Sample \% \\
\hline Both parents with college education (B) & $\mathrm{x}$ & $\mathrm{x}$ & 16 \\
Neither parent with college education (N) & $\mathrm{x}$ & $\mathrm{x}$ & 72 \\
Use a VPN - yes & 38 & 20 & 25 \\
Believe in God or some type of Supreme Being - yes & 14 & 20 & 18 \\
Believe in some type of spiritual life after death - yes & 33 & 33 & 33 \\
Men and women equal for job opportunities - agree & 57 & 76 & 72 \\
Would do anything to avoid shaming my family - agree & 46 & 66 & 62 \\
Chinese values are important to keep - agree & 57 & 56 & 55 \\
Greatest responsibility in life is taking care of parents - agree & 30 & 52 & 46 \\
\hline
\end{tabular}

\subsection{Research Question 1}

Research Question 1 is: To what degree do political party membership, gender, academic major, belief system, parental occupation and parental education level predict ethical attitudes of Chinese undergraduate students? To address this question, a series of binary logistic regressions were conducted, with the outcome variables being the responses to the binary agreement questions pertaining to ethical attitudes (e.g., "copying on assignments is ok"). The predictors included in each regression were political party membership, gender, academic major, belief system, parents' 
occupations, and parents' education. To reduce issues of multicollinearity and data separation caused by having numerous dummy-coded variables in the model, the categories of several categorical predictors were collapsed. Specifically, the categories of academic major were collapsed into "business" and "other." The categories of students' belief system were collapsed into "none" "Buddhism" "Chinese folk beliefs" and "other." Parents' occupations were coded as "one or both parents unemployed" "both parents employed in same occupation" and "both parents employed with different occupations." All regressions were run initially including all predictors, and predictors were removed (if necessary) to achieve model convergence. Statistical significance was evaluated at the 0.5 level.

The overall model results are presented in Table 10. The regression predicting the responses to the item "if a shopkeeper gives too much change, it is ok to keep the extra money" was significant, $\chi^{2}(11)=23.66, p=.014$, indicating that the predictors collectively significantly predicted responses to this item. Individual regression coefficients showed that belief system was a significant predictor. Specifically, students who believed in Buddhism were 12.28 times as likely to agree with this item compared to students with no belief system $(p<.001)$, and students who believed in some "other" belief system were 5.97 times as likely to agree with this item compared to students with no belief system $(p=.014)$. No other individual predictors or regressions were significant.

Table 10. Binary Logistic Regressions Predicting Ethical Attitudes

\begin{tabular}{lllll}
\hline Item & $\chi^{2}$ & $d f$ & Sig. & McFadden $R^{2}$ \\
\hline Copying on assignments is ok. & 7.02 & 4 & .135 & 0.06 \\
Most students copy at least some assignments. & 18.56 & 11 & .069 & 0.03 \\
Cheating on exams is ok. & 0.58 & 4 & .965 & 0.01 \\
$\begin{array}{l}\text { Most students cheat on at least some exams. } \\
\text { If a shopkeeper gives too much change, it is ok to }\end{array}$ & 14.13 & 11 & .226 & 0.03 \\
$\begin{array}{l}\text { keep the extra money. } \\
\text { It is ok to break traffic rules if there are no street }\end{array}$ & 8.21 & 6 & .014 & 0.14 \\
cameras. & 3.76 & 6 & .223 & 0.06 \\
$\begin{array}{l}\text { Ethics can be postponed to gain wealth. } \\
\text { It is ok to temporarily break rules to achieve a goal. }\end{array}$ & 9.00 & 11 & .709 & 0.05 \\
\hline
\end{tabular}
4.4 Research Question 2

Research Question 2 is: To what degree do political party membership, gender, academic major, belief system, parental occupation and parental education level predict management principle attitudes of Chinese undergraduate students? To address this question, a series of binary logistic regressions were conducted, with the outcome variables being the responses to the binary agreement questions pertaining to management principles (e.g., "employment relationships are more important than job competency"). The predictors included in each regression were the same as the previous analysis. The overall model results are presented in Table 11. The regressions predicting the responses to the three items about gender equality were significant (all $p$-values $<.05$ ), indicating that the predictors collectively significantly predicted students' views about gender equality. In each of these regressions, gender was the only individually significant predictor, showing that men were less likely than women to agree that "men and women should be equal for job opportunities" (odds ratio $=0.32, p<.001$ ) and that "men and women should be equal for employment pay" (odds ratio $=0.34, p<.001$ ); men were more likely than women to agree that "men are better leaders than women" (odds ratio $=3.88, p<.001)$. The regression predicting the responses to the item "leaders in Chinese business must be controlling" was significant, $\chi^{2}(11)=22.24, p=.023$, indicating that the predictors collectively significantly predicted responses to this item. Individual regression coefficients showed that parents' education was a significant predictor such that students with parents who were both college-educated were less likely to agree with this item compared to students with no college-educated parents (odds ratio $=0.38, p=.003$ ). The regression predicting the responses to the item "managers and workers cannot be social friends" was significant, $\chi^{2}(8)=18.32, p=.019$, indicating that the predictors collectively significantly predicted responses to this item. Individual regression coefficients showed that parents' education was a significant predictor such that students with one college-educated parent (odds ratio $=6.27, p=.016$ ) or with parents who were both college-educated (odds ratio $=5.70, p=.013$ ) were more likely to agree with this item compared to students with no college-educated parents. No other individual predictors or regressions were significant. 
Table 11. Binary Logistic Regressions Predicting Management Principles

\begin{tabular}{llllll}
\hline Item & $\chi^{2}$ & $d f$ & Sig. & McFadden $R^{2}$ \\
\hline $\begin{array}{l}\text { Maintaining relationships is more important than } \\
\text { honesty. }\end{array}$ & 19.12 & 11 & .059 & 0.05 \\
$\begin{array}{l}\text { Employment relationships are more important than } \\
\text { job competency. }\end{array}$ & 11.77 & 11 & .381 & 0.06 \\
$\begin{array}{l}\text { Men and women should be equal for job } \\
\text { opportunities. }\end{array}$ & 42.67 & 11 & $<.001$ & 0.09 \\
$\begin{array}{l}\text { Men and women should be equal for employment pay. } \\
\text { Men are better leaders than women. }\end{array}$ & 21.50 & 11 & $<.001$ & 0.07 \\
$\begin{array}{l}\text { In business, sharing power with subordinates brings } \\
\text { better results. }\end{array}$ & 12.52 & 11 & .030 & 0.09 \\
$\begin{array}{l}\text { Leaders in Chinese business must be controlling. } \\
\text { Managers and workers cannot be social friends. }\end{array}$ & 22.24 & 11 & .326 & 0.02 \\
\hline
\end{tabular}

4.5 Research Question 3

Research Question 3 is: To what degree do political party membership, gender, academic major, belief system, parental occupation and parental education level predict attitudes about traditional Chinese culture of Chinese undergraduate students? To address this question, a series of binary logistic regressions were conducted, with the outcome variables being the responses to the binary agreement questions pertaining to views on traditional Chinese culture (e.g., "traditional Chinese values are important to keep"). The predictors included in each regression were the same as the previous analysis. The overall model results are presented in Table 12. The regression predicting the responses to the item "I would do anything to avoid shaming my family" was significant, $\chi^{2}(11)=34.61, p<.001$, indicating that the predictors collectively significantly predicted responses to this item. Individual regression coefficients showed that gender was a significant predictor such that men were less likely to agree with this item compared to women (odds ratio $=0.50, p=.003)$. Party membership was also a significant predictor such that members of the Chinese Communist Youth League were more likely to agree with this item compared to members of the Chinese Communist Party (odds ratio $=2.68, p=.010$ ). The regression predicting the responses to the item "my greatest responsibility in life is making sure I can take care of my parents" was significant, $\chi^{2}(11)=30.76, p=.001$, indicating that the predictors collectively significantly predicted responses to this item. Individual regression coefficients showed that gender was a significant predictor such that men were less likely to agree with this item compared to women (odds ratio $=0.50, p=.003$ ). Parents' education was also a significant predictor such that students with parents who were both college-educated were less likely to agree with this item compared to students with no college-educated parents (odds ratio $=0.51, p=.033$ ). No other individual predictors or regressions were significant.

Table 12. Binary Logistic Regressions Predicting Affinity for Traditional Chinese Culture

\begin{tabular}{lllll}
\hline Item & $\chi^{2}$ & $d f$ & Sig. & McFadden $R^{2}$ \\
\hline I would do anything to avoid shaming my family. & 34.61 & 11 & $<.001$ & 0.06 \\
Traditional Chinese values are important to keep. & 16.20 & 11 & .134 & 0.03 \\
Harmony is more important than resolving conflict. & 19.00 & 11 & .061 & 0.03 \\
$\begin{array}{l}\text { My greatest responsibility in life is making sure I can } \\
\text { take care of my parents. }\end{array}$ & 30.76 & 11 & .001 & 0.05 \\
\hline
\end{tabular}

\section{Discussion}

\subsection{East Meets West Descriptive Comparisons}

This research reveals a limited look at the rapidly changing face of Chinese youth and of Chinese society on the larger scale. Employment of students' fathers revealed small business owner (25\%), farmer (21\%), works at home (14.36\%), and laborer (13.61\%) as the most common. Respondents at $23 \%$ had no siblings and $51 \%$ had only one sibling, parental financial support for school was $84 \%$, and $71 \%$ of parents had no college education. These respondents are unique in that most are the first generation in the immediate or extended family to attend higher education. An interesting contrast is made to the American counterpart in undergraduate schools where $60 \%$ of students receive no financial help from their parents and where the average American student loan debt for the Class of 2016 is $\$ 37,172$ (Mitchell, 2016). 
Many students responded they would do anything to keep from shaming their family (62\%), and many see their greatest responsibility in life as taking care of their parents (46\%). These reflect traditional Chinese values however only $55 \%$ agreed traditional Chinese values are important to maintain, possibly due to female respondents who equate traditional Chinese culture with a male dominated society (Emrich, Denmark \& Hartog, 2004). Student membership in the Chinese Communist Party (9\%) and membership in the Chinese Communist Youth League (87\%) contrasts with only 58\% of American millennials (18-33 years old) who say they love America (Vavreck, 2014). As noted previously however, classes on Chinese Communist Party teaching and nationalism are mandatory for all Chinese students.

As of 2014, official Chinese estimates of unaffiliated/Chinese folk religion accounts for $74 \%$ of Chinese with Christianity at only $2.53 \%$ (Wenzel-Teuber, 2017). The student combined answer of 'None' (83\%) and Chinese Folk Beliefs (2\%) at $85 \%$ is substantially higher than the official estimate in 2014. According to these research results, the absence of any belief system (83\%) is on the increase as a result of Chinese government efforts with an average of grandparents at $68 \%$ and parents at $82 \%$. Nevertheless, more than $18 \%$ of students said they believed in God or a Supreme Being and 33\% said they believed in some type of spiritual life after death. In America, 57\% of college graduates believe in God or a Supreme Being (Pew Research Center, 2018).

Students reported $58 \%$ do not drink versus $41 \%$ of their American peers (National Institute on Alcohol Abuse and Alcoholism, 2015). In addition, $21 \%$ of respondents agreed that Chinese business culture requires a man to be able to drink large amounts of alcohol. Smoking reveals a similar difference with respondents at $90 \%$ never smoking versus their American counterparts at 71\% (Sutfin, McCoy, Berg, Champion, Helme, O’Brien, \& Wolfson, 2012). Students at $66 \%$ agreed there is no absolute truth and $43 \%$ agreed that truth depends on the situation. The Eastern emphasis on harmony was represented in $17 \%$ of respondents agreeing that maintaining relationships is more important than honesty and $41 \%$ agreeing that harmony is more important than resolving conflict.

\subsection{Crosstab Analysis}

Business students accounted for the largest majority of respondents at $42 \%$. Of all majors, business students scored lowest (12\%) agreeing that maintaining relationships is more important than honesty. The same group was evenly split on the question of male and female equal pay for equal work but low $(8 \%)$ in agreeing that men are better leaders than women. Of students whose fathers are small business owners (25\%), 51\% agreed that truth depends on the situation, $54 \%$ agreed they trust most people around them, and only $10 \%$ agreed that maintaining relationships is more important than honesty. These students were low (56\%) in agreeing males and females should receive equal pay.

Student members of the Chinese Communist Party (CCP) accounted for 9\% of respondents and those that were members of the Chinese Communist Youth League (CCYL) were $87 \%$. Crosstab analysis revealed differences indicating CCP students at almost twice the percentage of CCYL students use a VPN. In addition, those of the CCP group scored higher in the area of ancillary spiritual beliefs, lower in gender equality, shielding the family from shame, and in terms of being responsible for parents. The crosstab analysis on parents' level of education indicates a negative correlation between educated parents and compliance with VPN restrictions, agreement with gender equality for job opportunities, protecting the family from shame, and responsibility for taking care of one's parents.

\subsection{Binary Logistic Regression Analysis}

Research Question 1 results indicate Chinese undergraduate student political party membership, gender, academic major, belief system, parents' occupations and education were predictive of binary responses regarding ethical attitudes. The most significant item in this group was, "If a shopkeeper gives too much change, it is ok to keep the extra money." This result can be explained in part by the collectivistic nature of Chinese culture where easy distinctions are made between, "us" and "them" (Gelfand, Bhawuk, Nishii, \& Bechtold, 2004). In order for an individual to move from a "them" category to the "us" category, Chinese culture includes a complex and lengthy process required to develop reciprocal relationships that go far beyond a Western understanding of acquaintance or friendship. The predictors were also significant regarding cheating on exams and assignments. This indicates that, if Chinese students have the opportunity, incidences of academic dishonesty are not uncommon. However, the Chinese cultural subtleties on this ethical item are difficult to explain and even more difficult to understand from a Western viewpoint. It may be explained in succinct terms by millennia old traditions honoring masters with excellent copies of original work coupled with a lack of emphasis on Western ethical ideals of academic honesty in the Chinese classroom.

Research Question 2 results indicate the same predictors were significant for a number of items, most notably with regard to gender. In Chinese masculine culture (House et al., 2004) it is not surprising males favor equal pay and opportunity less than females particularly with the intense competition for employment among more than eight million Chinese college graduates each year (Stapleton, 2017). The high power distance (Carl, Gupta \& Javidan, 2004) and performance orientation (Javidan, 2004) in Chinese culture explains in part the significant responses to the statement that leaders in Chinese business must be controlling. The liberalizing effect of higher education is apparent noting that 
students whose parents both had college education were less likely to agree with this statement versus those whose parents had no college education.

Research Question 3 results indicate the same predictors were significant for items relating to Chinese cultural norms (Kabasakal \& Bodur, 2004). The heavy reliance on family support systems in China is reflected in the significant prediction relationship to, "I would do anything to avoid shaming my family," and "My greatest responsibility in life is making sure I can take care of my parents." Notwithstanding these outcomes, it is noteworthy that Chinese Communist Party members were less likely to agree that it is imperative to do anything to avoid shaming one's family. The selective and difficult process of becoming a Chinese Communist Party member and the resulting additional indoctrination of nationalistic ideals may account for what might be considered as valuing country over family. In addition, as might be expected, females were more likely to agree that they are responsible for their parents. This presents a difficult dilemma for Chinese students in that the parents of the husband are traditionally viewed as the priority for a married couple and the one child policy until a year ago has resulted in a high number of one child families who have a daughter. Furthermore, Chinese society and traditional ideals are under pressure for change as per capita wealth and access to higher education increase. This is reflected in students of college educated parents being less likely to agree they have responsibility to care for their parents.

\section{Limitations}

The outcomes of this study are limited because the study drew participants from only one university in rural China. In addition, students at the university used in this study may be a different cross-section of the more general undergraduate university population in China because the school is known as a Tier Three school. In China, high school students all take a national exam known as the Gaokao. How they perform on that examination determines what school they will attend.

Top performing students attend Tier One schools and costs are borne primarily by the State. The next level of students are offered positions at Tier Two schools, where the State also pays the majority of the cost. Tier Three schools are available for those students who did not qualify for the Tier One or Tier Two schools. Tier Three schools require private funding however some government and other scholarships are available on a limited basis. Students' enrollment at a Tier Three school does not indicate low cognitive ability. Rather, their performance on the Gaokao was less than ideal during the two-day examination, or their home province is densely populated and there is increased competition for a limited number of university enrolment options.

It is possible that the sample in this study is not representative of Chinese students. Relationships and findings from this data do not indicate causation and only offer data for the formulation of possible relationships. Furthermore, because data were collected at a single time, there is the possibility that data collected at another time might produce different results and thus the relationships between variables identified above may be over- or underestimated.

\section{Conclusion}

This study contributes to existing literature to understand the motivations that guide business and management decision-making in China according to contemporary thinking. Further research, discussion, and commentary should focus on broadening the results and discussion in this paper. This narrow and limited view of those variables that impact Chinese students at the subject university regarding their worldviews and analytical approach is helpful under the qualifications as stated herein. The goal of improving cross-cultural understanding and the efficacy of adaptations in and outside the management classroom is advanced.

\section{Compliance with Ethical Standards}

Ethical approval: The author received IRB approval for this study and has complied with ethical standards. This article involved human participants and each respondent agreed to participate through an informed consent.

\section{Conflict of Interest}

The author declares no conflict of interest.

\section{References}

Balsas, C. (2003). Sustainable transportation planning on college campuses. Transportation Policy, 10, 35-49. https://doi.org/10.1016/S0967-070X(02)00028-8

Baltar, F., \& Brunet, I. (2012). Social research 2.0: virtual snowball sampling method using Facebook. Internet Research, 22(1), 57-74. https://doi.org/10.1108/10662241211199960.

Beechler, S., \& Javidan, M. (2007). Leading with a global mindset. In Javidan, M., Steers, R. \& Hitt, M. (Eds.), Advances in international management: The global mindset. Oxford: Elsevier/JAI Press. 
https://doi.org/10.1016/S1571-5027(07)19006-9

Bennett, M. J. (2004). Becoming interculturally competent. In J.S. Wurzel (ed.) Toward multiculturalism: A reader in multicultural education. Newton, MA: Intercultural Resource Corporation.

Bennett, M. J., \& Salonen, R. (2007). Intercultural communication and the new American campus. Change, 39(2), 4650. https://doi.org/10.3200/CHNG.39.2.46-C4

Bird, A., Medenhall, M., Oddou, G., \& Stevens, M. (2010). Defining the content domain of intercultural competence for global leaders. Journal of Managerial Psychology, 25(8), 810-828. https://doi.org/10.1108/02683941011089107

Bonn, G., \& Lian, T. C. (2016). Imagining a good life in Malaysia and China: Cultural beliefs among Mainland Chinese, Malaysian Chinese, and Malay University students. Asian Journal of Social Psychology, 19, 145-153. https://doi.org/10.1111/ajsp.12120

Caplovitz, D. (1977). Religious dropouts: Apostasy among college graduates. Newcastle upon Tyne: SAGE.

Carl, D., Gupta, V., \& Javidan, M. (2004). Power Distance. In R. J. House, P. J. Hanges, M. Javidan, P. W. Dorfman \& V. Gupta (Eds.), Culture, leadership and organizations: The GLOBE Study of 62 Societies (pp. 513-563). Thousand Oaks: Sage.

Chemers, M. M. (1995). Contemporary leadership theory. In J.T. Wren (Ed.), The leader's companion; Insights on leadership through the ages (pp. 83-99), New York: The Free Press.

Cheng, Y. C. (2005). New Paradigm for Re-engineering Education - Globalization, Localization, and Individualization. Dordrecht, Netherlands: Springer.

Crede, J., Wirthwein, L., McElvany, N., \& Steinmayr, R. (2015). Adolescents' academic achievement and life satisfaction: The role of parents' education. Frontiers in Psychology, 6(52), 1-8. https://doi.org/10.3389/fpsyg.2015.00052

Crotty, M. (1998). The foundations of social research: Meaning and perspective in the research process. London: Sage.

Diaz-Rico, T. L., \& Weed, Z. K. (2010). The cross-cultural, languages, and academic development handbook: A complete K-12 reference guide. Boston, MA: Pearson Education, Inc.

Dorfman, P., Hanges, P., \& Brodbeck, F. C. (2004). Leadership and cultural variation: The identification of culturally endorsed leadership profiles. Culture, Leadership, and Organizations: The GLOBE Study of 62 Societies (pp. 669-719). Thousand Oaks: Sage.

Durant, A., \& Shepherd, I. (2009). "Culture" and "communication" in intercultural communication. European Journal of English Studies, 13(2), 147-162. https://doi.org/10.1080/13825570902907185

Emrich, C. G., Denmark, F. L., \& Hartog, D. N. (2004). Cross-cultural differences in gender egalitarianism: Implications for societies, organizations, and leaders. In R.J. House, P.J. Hanges, M. Javidan, P.W. Dorfman \& V. Gupta (Eds.), Culture, leadership, and organizations: The GLOBE Study of 62 Societies (pp. 343-394). Thousand Oaks, CA: Sage.

Erdfelter, E., Faul, F., Lang, A., \& Buchner, A. (2007). G*Power 3: A flexible statistical power analysis program for the social, behavioral, and biomedical sciences. Behavioral Research Methods, 39(2), 175-191. https://doi.org/10.3758/BF03193146

Erdvik, I. B., Overby, N. C., \& Haugen, T. (2015). Translating, reliability testing, and validating a Norwegian questionnaire to assess adolescents' intentions to be physically active after high school graduation. SAGE Open, June 19, 2015. Retrieved from https://doi.org/10.1177/2158244015580374

Fall, L. T., Kelly, S., MacDonald, P., Primm, C., \& Holmes, W. (2013). Intercultural communication apprehension and emotional intelligence in higher education: Preparing business students for career success. Business Communication Quarterly, 76(4), 412-426. https://doi.org/10.1177/1080569913501861

Friend, J., Most, R., \& McCrary, K. (2009). The impact of a professional development program to improve urban middle-level English language learner achievement. Middle Grades Research Journal, 4(1), 53-75. Retrieved from http://www.infoagepub.com/middle-grades-research-journal

Garcia, P. R., Restubog, S. I., Toledano, I. S., Tolentino, I. R., \& Rafferty, A. E. (2011). Differential moderating effects of student and parent-rated support in the relationship between learning goal orientation and career decision-making self-efficacy. Journal of Career Assessment, 20, 22-23.

https://doi.org/10.1177/1069072711417162

Gelfand, M. J., Bhawuk, D. P. S., Nishii, L. H., \& Bechtold, D. J. (2004). Individualism and collectivism. In R. J. House, 
P. J. Hanges, M. Javidan, P. W. Dorfman \& V. Gupta (Eds.), Culture, leadership, and organizations: The GLOBE Study of 62 Societies (pp. 437-512). Thousand Oaks, CA: Sage.

Giddens, A. (2003). Runaway world: How globalization is reshaping our lives. New York: Routledge.

Ginerva, M. C., Nota, I., \& Ferrari, I. (2015). Parental support in adolescents' career development: Parents' and children's perceptions. Career Development Quarterly. 63, 2-15. https://doi.org/10.1002/j.2161-0045.2015.00091.x

Goldsmith, M., Walt, C., \& Doucet, K. (2000). New competencies for tomorrow's global leader. CMA Management, 73(10), 20-26.

Goryunova, E., \& Jenkins, D. M. (2017). Global Leadership Education: Upping the game. Journal of Leadership Education, 16(4), 76-93. https://doi.org/10.12806/V16/I4/A1

Guan, P., Capezio, A., Restubog, S., Read, S., Lajom, J., \& Li, M. (2016). The role of traditionality in the relationships among parental support, career decision-making self-efficacy and career adaptability. Journal of Vocational Behavior, 94, 114-123. Retrieved from http://dx.doi.org/10.1016/jjvb.2016.02.018.

Habermas, T., \& Bluck, S. (2000). Getting a life: The emergence of a life story in adolescence. Psychology Bulletin, 126, 748-769. https://doi.org/apa.org/journals/bul/126/5/748.

Hauser, R. M. (1994). Measuring socioeconomic status in studies of child development. Child Development. 65, 1541-1545. https://doi.org/10.2307/1131279

Henrich, J, Heine, S. J., \& Norenzayan, A. (2010). The weirdest people in the world? Behavioral and Brain Sciences, 33, 61-83. https://doi.org/10.1017/S0140525Xo999152X

Hofstede, G., \& Hofstede, G. J. (2005). Cultures and organizations: Software of the mind. New York: McGraw-Hill.

House, R. J., Hanges, P. J., Javidan, M., Dorfman, P. W., \& Gupta, V. (Eds.). (2004). Culture, leadership, and organizations: The GLOBE Study of 62 Societies. Thousand Oaks, CA: Sage.

Hu, G., \& Lei, J. (2014). Chinese university students' perceptions of plagiarism. Ethics \& Behavior, 25(3), 233-255. Retrieved from http://dx.doi.org/10.1080/10508422.2014.923313.

Huang, F. (2015). Building the world-class research universities: A case study of China. Higher Education, 70(2), 203-215. https://doi.org/10.1007/s10734-015-9876-8

Hunter, J. D. (1983). American Evangelicalism: Conservative religion and the Quandary of modernity. New Brunswick: Rutgers University Press.

Javidan, M. (2004). Performance orientation. In R. J. House, P. J. Hanges, M. Javidan, P. W. Dorfman \& V. Gupta (Eds.), Culture, leadership, and organizations: The GLOBE Study of 62 Societies (pp. 239-281). Thousand Oaks: Sage.

Jones, E., \& Killick, D. (2013). Graduate attributes and the internationalized curriculum: Embedding a global outlook in disciplinary learning outcomes. Journal of Studies in International Education. 17(2), 165-182. https://doi.org/10.1177/1028315312473655

Kabasakal, H., \& Bodur, M. (2004). Humane orientation in societies, organizations, and leader attributes. In R. J. House, P. J. Hanges, M. Javidan, P. W. Dorfman \& Gupta, V. (Eds.), Culture, leadership, and organizations: The GLOBE Study of 62 Societies (pp. 564-601). Thousand Oaks, CA: Sage.

Kadison, R., \& DiGeronimo, T. F. (2004). College of the overwhelmed: The campus mental health crisis and what to do about it. San Francisco, CA: Jossey-Bass.

Kim, Y., \& Sherraden, M. (2011). Do parental assets matter for children's educational attainment? Evidence from mediation tests. Children and Youth Services Review, 33, 969-979. https://doi.org/10.1016/j.childyouth.2011.01.003

Komives, S. R., Lucas, N., \& McMahon, T. R. (2007). Exploring leadership: For college students who want to make a difference (2nd ed.). San Francisco: Jossey-Bass.

La Roche, C. (2011). Looking East: Yin and yang of an academic exchange. Journal of International Education Research, 7(2), 47-54. https://doi.org/10.19030/jier.v7i2.4249

Lee, J. J., \& Rice, C. (2007). Welcome to America? International student perceptions of discrimination. Higher Education, 53(3), 381-409. https://doi.org/10.1007/s10734-005-4508-3

Leedy, P. D., \& Ormrod, J. E. (2010) Practical Research: Planning and Design (9th ed.). Upper Saddle River, NJ: 
Pearson Education.

Lehman, E. C., \& Shriver, D. W. (1968). Academic discipline as predictive of faculty religiosity. Social Forces, 47, 171-182. https://doi.org/10.1093/sf/47.2.171

Leung, S. A., Hou, Z. J., Gati, I., \& Li, X. (2011). Effects of parental expectations and cultural-values orientation on career decision-making difficulties of Chinese university students. Journal of Vocational Behavior, 78, 11-20. https://doi.org/10.1016/j.jvb.2010.08.004

Li, D. (2007). Improving the quality of theses in the social sciences and humanities. China Adult Education, 9, 114-115.

Li, L., \& Wegerif, R. (2014). What does it mean to teach thinking in China? Challenging and developing notions of Confucian education. Thinking Skills and Creativity, 11, 22-32. https://doi.org/10.1016/j.tsc.2013.09.003

Li, M., Lu, Y., \& Yang, F. (2018). Shaping the religiosity of Chinese University Students: Science education and political indoctrination. Religions, 9, 309-320. https://doi.org/10.3390/re19100309

McInerney, D. M., \& Liem, A. D. (2008). Teaching and learning: International best practice. Charlotte, NC: IAP.

Mendenhall, M., Osland, J., Bird, A., Oddou, G., \& Maznevski, M. (2008). Global leadership: research, practice and development. New York, NY: Routledge.

Mitchell, J. (2016, May 2). Student debt is about to set another record, but the picture isn't all bad. Wall Street Journal. Retrieved from

https://blogs.wsj.com/economics/2016/05/02/student-debt-is-about-to-set-another-record-but-the-picture-isnt-all-bad/

Moro, C., \& Tubbs, S. (2004). Identifying global leadership competencies. An exploratory study. Journal of American Academy of Business, 5(1/2), 80-87.

$\mathrm{Mu}, \mathrm{Z}$., \& Xu, R. (2009). Causes of and strategies for dealing with undergraduate students' academic dishonesty. Journal of Inner Mongolia University of Technology, 18(2), 82-84.

National Institute on Alcohol Abuse and Alcoholism, December 2015. Retrieved from https://pubs.niaaa.nih.gov/publications/collegefactsheet/Collegefactsheet.pdf

Niezen, M. G. H., \& Mathijssen, J. J. P. (2014). Reframing professional boundaries in healthcare: A systematic review of facilitators and barriers to task reallocation from the domain of medicine to the nursing domain. Health Policy, 117(2), 151-169. https://doi.org/10.1016/j.healthpol.2014.04.016

O’Brien, T. L., \& Noy, S. (2015). Traditional, modern and post-secular perspectives on science and religion in the United States. American Sociological Review, 80, 92-115. https://doi.org/10.1177/0003122414558919

Ozturgut, O. (2007). Teaching West in the East: An American university in China. International Journal of Teaching and Learning in Higher Education, 19(3), 228-237. Retrieved from http://www.isetl.org/ijtlhe/

Perkins, A. W. (2009). Global leadership study: A theoretical framework. Journal of Leadership Education, 8(2), $72-87$. https://doi.org/10.12806/V8/I2/TF2

Pettigrew, A. (1979). On studying organizational cultures. Administrative Science Quarterly, 24, 570-581. https://doi.org/10.2307/2392363

Pew Research Center (2018). Religious Landscape Study. Pew Research Center's Forum on Religion and Public Life, 2018. Retrieved from http://www.pewforum.org/religious-landscape-study/educational-distribution/college/

Qin, Z. (2013). A study of Chinese learners' recognition of plagiarism. Foreign Languages and Their Teaching, 269, 26-30.

Quinn, N. (2003). Cultural selves. Annals of the New York Academy of Science, 1001, 145-176. https://doi.org/10.1196/annals.1279.010

Rana, R. A., \& Mahmood, N. (2010). The relationship between test anxiety and academic achievement. Bulletin of Educational Research, 32, 63-74.

Rawwas, M. Y., Al-Khatib, J. A., \& Vitell, S. J. (2004). Academic dishonesty; A cross-cultural omparison of U.S. and Chinese marketing students. Journal of Marketing Education, 26(1), 89-100.

Ryan, J. (2011). Teaching and learning for international students: Towards a transcultural approach. Teachers and Teaching, 17(6), 631-648. https://doi.org/10.1080/13540602.2011.625138

Savikas, M. I. (2013). Career construction theory and practice. In S.D. Brown \& R.W. Lent (Eds.) Career development and counseling: Putting theory and research to work (pp. 42-70)(2 ${ }^{\text {nd }}$ ed.). Hoboken: Wiley.

Schein, E. (1992). Organizational culture and leadership (2nd ed.). California: Jossey-Bass. 
Schwartz, H., \& Davis, S. (1981). Matching corporate culture and business strategy. Organizational Dynamics, 33. https://doi.org/10.1016/0090-2616(81)90010-3

Shek, D. T. \& Lin, L. (2016). Changes in university students after joining a service leadership program in China. Journal of Leadership Education, 15(1), 96-109. https://doi.org/10.12806/V15/I1/A2

Sirin, S. R. (2005). Socio-economic status and academic achievement: A meta-analytic review of research. Review of Educational Research, 75, 417-453. https://doi.org/10.3102/00346543075003417

Spencer-Oatey, H., Dauber, D., Jing, J., \& Lifei, W. (2017). Chinese students' social integration into the university community: Hearing the students' voices. Higher Education, 74(5), 739-756. https://doi.org/10.1007/s10734-016-0074-0

Stapleton, K. (2017). China nor produces twice as many graduates a year as the U.S. Retrieved from https://www.weforum.org/agenda/2017/04/higher-education-in-china-has-boomed-in-the-last-decade.

Steinmayr, R., Meisner, A., Weidinger, A. F., \& Wirthwein, L. (2011). Academic achievement. In Oxford Bibliographic Online: Education, ed. L.H. Meyer. New York: Oxford University Press.

Sutfin et al. (2012). Tobacco Use by College Students: A Comparison of Daily and Nondaily Smokers. American Journal of Health Behavior, 36(2), 218-229. https://doi.org/10.5993/AJHB.36.2.7

Tang, E. (2009). A cultural framework of "Chinese learn English": A critical review of and reflections on research. Journal of English as an International Language, 4, 7-43. Retrieved from http://www.eilj.com.

Tian, Y. \& Fan, X. (2014). Adversity quotients, environmental variables and career adaptability in student nurses. Journal of Vocational Behavior, 85, 251-257. https://doi.org/10.1016/j.jvb.2014.07.006

Turner, S. L., Alliman-Brissett, A., Lapan, R. T., Udipi, S., \& Ergun, D. (2003). The career-related parent support scale. Measurement and Evaluation in Counseling and Development, 36, 83-94.

Vavreck, L. (2014, July 4). Younger Americans are less patriotic. At least, in some ways. New York Times. Retrieved from https://www.nytimes.com/2014/07/05/upshot/younger-americans-are-less-patriotic-at-least-in-some-ways.html

Wenzel-Teuber, K. (2017). Statistics on religions and churches in the People's Republic of China - Update for the year 2016. Religions \& Christianity in Today's China. VII (2). pp. 26-53. Retrieved from http://www.china-zentrum.de/fileadmin/downloads/rctc/2017-2/RCTC_2017-2.26-53_Wenzel-

Xue, Y. H., \& Xue, I. (2002). The spatial distribution of China's higher education system. Journal of Higher Education, 23(4), 44-49.

Yang, F. (2015). The other Chinese miracle. Association of Religion Data Archives. December 1. Retrieved from http://globalplus.thearda.com/globalplus-religion-in-china

Yang, K. S. (2003). Methodological and theoretical issues on psychological traditionality and modernity research in an Asian society: In response to Kwang-Kuo Hwang and beyond. Asian Journal of Social Psychology, 6, 263-285.

Yuan, R., Li, S., \& Yu, B. (2018). Neither "local" nor "global": Chinese university students' identity paradoxes in the internationalization of higher education. Higher Education. Online, September 25, 2018. Retrieved from https://doi.org/10.1007/s10734-018-0313-7.

Zhang, X. (2012). Preventing plagiarism in thesis writing in higher education. Academic Degrees \& Graduate Education, 9, 73-77.

Zimmerman, J. (2015). Lessons from abroad: Teaching cultural and global leadership in the U.S. classroom. Journal of Leadership Education, 14(4), 114-125.

\section{Copyrights}

Copyright for this article is retained by the author(s), with first publication rights granted to the journal.

This is an open-access article distributed under the terms and conditions of the Creative Commons Attribution license which permits unrestricted use, distribution, and reproduction in any medium, provided the original work is properly cited. 